\title{
Promoting Organizational Citizenship Behavior among Employees - The Role of Leadership Practices
}

\author{
Hamed Al-sharafi ${ }^{1} \&$ Ismi Rajiani ${ }^{1}$ \\ ${ }^{1}$ Faculty of Technology Management and Technopreneurship, Universiti Teknikal Malaysia Melaka, Malaysia \\ Correspondence: Hamed Al-sharafi, B-18-8 Idaman Sutera, Medan Idaman, Gombak, 53100, Kuala Lumpur, \\ Malaysia. Tel: 60-1-7356-2150. E-mail: Hamed.Ali.Sh@gmail.com
}

Received: December 13, 2012 Accepted: January 8, 2013 Online Published: February 20, 2013

doi:10.5539/ijbm.v8n6p47

URL: http://dx.doi.org/10.5539/ijbm.v8n6p47

\begin{abstract}
Despite of numerous studies that investigate the relationship between leadership and The Organizational Citizenship Behavior, very few of these studies have examined the influences of leadership practices - as defined by Kouzes and Posner (1987) - on organizational citizenship behaviors. Moreover, most of these studies have been conducted in western context (developed counties). In this regard, current study has three main purposes: first, investigate the influences of leadership practices on organizational citizenship behaviors. Second, conduct this investigation in Arabic context (developing country). The third purpose of this study is to investigate the mediating effect of organizational commitment on the relationship between leadership practices and organizational citizenship behaviors.

Using the response of 108 non managerial banks employees, the result indicated that leadership practices have a significant positive impact in the organizational commitment and OCB. The results of the study found that organizational commitment does partially mediate the relationship between leadership practices and Organizational Citizenship Behavior.
\end{abstract}

Keywords: leadership practices, organizational citizenship behavior, organizational commitment, Yemen

\section{Introduction}

Organizational Citizenship Behavior (OCB) is one of the main topics that get practitioners and researchers attention and interests (Change \& Chelladurai 2003). This is because of the positive impact that OCB has on different aspects of organizations. According to Organ (1988), high levels of OCB lead to high levels of organizational efficiency, effectiveness and adaptability. It is considered as one of the most important factors influencing organizational effectiveness. Walz and Niehoff (2000) found the OCB dimensions enhance organizational efficiency, performance, and customer satisfaction. Furthermore, OCB is positively related to high job performance, productivity, efficiency, cost reduction, profitability, employees' retention and customer satisfaction (Podsakoff, Whiting, Podsakoff, \& Blume, 2009).

Many studies have been done to identify the factors that enhance and promote OCB. Factors related to personal characterics, organizational environment, and leadership behaviors found to predict different types of OCB (Podsakoff, Mackenzie, Paine, \& Bachrach 2000). Furthermore, Jahangir, Akbar and Haq (2004) argued that like most behaviors, there is no single cause of OCB. It is subject to multiple antecedents. Although there are many studies that identified the factors that promote or enhance the OCB in organizations, very few studies examined the linkage of leadership practices with OCB where the effect of organizational commitment as a mediator is included. As a result of that, Current study attempts to answer two main questions. Do leadership practices promote employees' OCB? Does organizational commitment mediate the relationship between leadership practices and OCB?

\section{Theoretical Framework}

This study examines the relationship between leadership practices and OCB with organizational commitment as a mediator. This relationship is expressed as Figure 1, which shows the five practices of leadership. According to Kouzes \& Posner (1987), leadership is a set of practices of exemplary behavior. They have developed a model of leadership practices contains five main practices that are important for leaders to be consider as a real leaders. These practices are: modeling the way, inspiring a shared vision, challenging the process, enabling others to act, 
and encouraging the heart.

Modeling the way emphasizes that Leaders should clarify values, set high standard of achievement and excellence, and give a good example for others to follow. Inspiring a shared vision refers to Leadership ability to spread his ambitious vision regarding what he or she - as a leader- wants to achieve at the end (long term future). In addition, challenging the process defined as the leader's ability to question the status quo (Bennis \& Nanus, 1985; Mirza, 2005). Moreover, enabling others to act describes the Leader's ability to foster collaboration, build trust, and empowerment. They encourage teamwork and actively involve others. Finally, encouraging the heart is the process of recognizing and appreciation of the employee efforts and contributions.

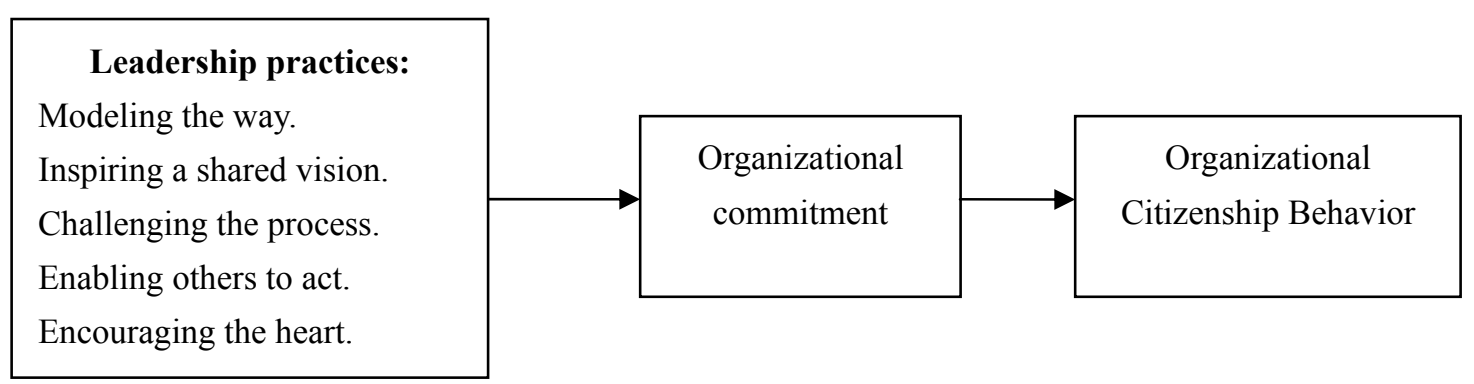

Figure 1. The relationship between leadership practices and organizational citizenship behavior and the mediating influence of organizational commitment

\subsection{Leadership Practices and Organizational Citizenship Behavior}

Kouzes and posner (1987) defined leadership as the art of mobilizing others to want to struggle for shard aspirations. So, leadership is a process in which the leader influences others - their actions and attitudes - to accomplish an objective and directs the organization in a way that makes it successful. Leaders are usually considered the main influencers on employees behavior (Kozlowski\& Doherty 1989). Therefore, Leaders are most likely to play a key role in influencing organizational citizenship behaviors (OCBs) (Lin, Li \& Hsiao 2012). In fact, previous studies have found a positive relationship between leadership and OCB (Lin et al. 2012; Podsakoff, MacKenzie \& Bommer 1996).

In regard of Organizational Citizenship Behavior, Organ (1988) defined OCB as behaviors that are "discretionary, not directly or explicitly recognized by the formal reward system, and that in the aggregate promote the effective functioning of the organization" (p. 4). He identified five dimensions of OCB: (1) altruism -- employees help coworker with job relevant duties and tasks, (2) courtesy - being polite, considerate of others, and treat them with respect, (3) conscientiousness - when employee goes beyond normal requirements or expectations (Podsakoff, MacKenzie, Moorman \& Fetter 1990)., (4) sportsmanship employees have a positive attitude and are willing to tolerate less than ideal circumstances without complaining, and (5) civic virtue -- participating in the governance of the organization. Podsakoff and MacKenzie (1994) in more recent conceptualizations of OCB combined both altruism and courtesy and into new dimension termed it "helping" (Yen \& Niehoff, 2004).

Over time, a number of theories of leadership have been proposed. There are number of main theories such as traits theory, behavioral theories, situational theories, and transformational/transactional theory. There has been empirical research that demonstrate the relationship between different types of leadership behaviors and OCB such as servant leadership and OCB (Walumbwa, Hartnell, \& Oke, 2010), transformational leadership and OCB (Cho \& Dansereau, 2010 Organ, 1988; Podsakoff et al., 1990), charismatic leadership (Deluga 1995; Sosik 2005), and authentic leadership (Stewart Wherry, 2012). In addition, number of studies indicated that leadership member exchange (LMX) had positive impact on OCB (Asgari, Silong, Ahmed, \& Abu Samah 2008). As mentioned earlier, the lack of studies that examine the leadership practices and OCB developed the following hypothesis:

Hypothesis 1: leadership practices are positively related to OCB.

\subsection{Organizational Commitment as a Mediator}

Organizational commitment defined as employees' psychological state that influences the desire to remain a member of the organization (Meyer \& Allen, 1991). Early studies on organizational commitment introduced this concept as single dimension. More recent studies see it as a multidimensional concept. In this regard, Meyer and 
Allen (1990) have identified three commitment of Organizational commitment: Affective commitment- refers to the emotional attachment between the employee and the organization; normative commitment refers to individual's moral obligation to remain in an organization (Meyer et al 1991); Continuance commitment related to the tendency of staying in the organization due to the benefits of staying or expenses of leaving the organization.

According to Meyer and Allen (1996) Organizational commitment is the main construct in order to understand the relationship between the employee and the employer. Hedberg and Helenius (2007) believe that leadership has become a key factor in increasing employees' commitment and reducing employees' turnover. Hay (2002) argues that bad management result in employees' turnover. Although many studies have shown that that leadership style has a significant relationship with commitment to the organization (Walumbwa, Orwa, Wang, \& Lawler 2005; Bono \& Judge 2003), some studies found no relationship between (Hampton, Dubinsky, \& Skinner, 1986).

The relationship between organizational commitment and OCB has been demonstrated by many studies (Organ, 1988; Van Scotter, 2000; Wagner \& Rush, 2000). In fact, it is expected that employees with high level of commitment to their organization are more focused on their work than employees reporting lower levels (Van Scotter, 2000). According we have hypothesized as follow:

Hypothesis 2: organizational commitment mediates the relationship between leadership practices and OCB.

\section{Methodology}

\subsection{The Study Setting}

Yemen is a country in the Middle East located in the Arabian Peninsula (Arabia). The national language is Arabic. The banking system in Yemen consists of 16 commercial banks (nine private domestic banks, four of which are Islamic banks; five private foreign banks; and two state-owned banks), and two specialized state-owned development banks.

\subsection{Sample}

The sample was 160 non managerial employees from the main branches of the 16 commercial banks (10 questionnaires at each organization). A total of 117 questionnaires were returned, an approximate response rate of $73 \%$. Only 108 questionnaires were useful for purposes of the study, about $67.5 \%$.

\subsection{Procedure}

The data was collected through questionnaire from the 16 commercial banks. A brief explanation has been given to inform the respondents about the main objectives of the study so that they would be able to fill the questionnaire accurately. The questionnaires were handed to the HR manger in each bank of these commercial banks; he was requested to distribute four questionnaires at random to the employees. One week later the questionnaires were collected from the HR department.

\subsection{Measures}

Leadership Practices. The leadership practice is measured by the 30 items of leadership practices inventory (LPI) that developed by (Kouzes \& Posner 2003). It consists of 6 items for each of the five practices (modeling the way, inspiring a shared vision, challenging the process, enabling others to act, and encouraging the heart). The item ratings will be obtained from a five point Likert scale that had responsiveness ranging from $1=$ 'Seldom or rarely' to 5= 'Very Frequently'.

Organizational Citizenship Behaviors. For the purpose of this study, this variable was assessed with 24-items OCB scale developed by (Podsakoff, et al. 1990). This measurement assesses the five dimensions of OCB proposed by Organ (1988). These dimensions were altruism ( 5 items), conscientiousness ( 5 -items), courtesy (5 items), sportsmanship (5 items) and civic virtue (4 items). The measurement ranged from 1 = 'Strongly Disagree' to $5=$ 'Strongly Agree'.

Organizational Commitment. Organizational commitment was measured using (Mowday, Steers, \& Porter 1979) instrument. It consists of 15 items, the item ratings will be obtained from a five point Likert scale that had responsiveness ranging from $1=$ 'Strongly Disagree' to $5=$ 'Strongly Agree'.

\section{Analysis and Results}

Descriptive statistical methods have been used to describe the demographic profile of the respondents. The respondents comprised of 84 per cent males and 16 per cent females. This percentage reflected the workforce in yemen where the high majority of workforce are male, while female represent minority. Most employees were 
young, $80 \%$ of the respondent less than 35 years old. About $28 \%$ of them were less than 25 years old and $52 \%$ of them were within age of $25-35$ years, while $17 \%$ of them were from $35-45$ years of age and $3 \%$ of the respondents were more than 45 years old. Most of the respondents have have bachelor's degree $64 \%$, and $2 \%$ of them have master degree. About $14 \%$ of the respondents have high school level of education, while $20 \%$ have a diploma. Finally, there were $27 \%$ of respondents had less than 2 years of working experience, while $41 \%$ of them had from 2-5 years of working experience, $24 \%$ had from 5-10 years of working experience, and only $8 \%$ of them had from more than 10 years of working experience.

The means of the Leadership practices range from a maximum value of 3.64 (Enabling others to act) to a minimum value of 2.72 (Challenging the process), While the means of OCB Organizational commitment was 3.77, 3.54 respectively. Meanwhile, the coefficient alphas for the study variables were: Modeling the way .92 , challenging the process .93 , inspiring a shared vision .85 , enabling others to act .93 , encouraging the heart .80, Leadership practices (as a whole) .93; Organizational commitment .83; OCB .95. Overall, the means, standard deviations, and the coefficient alphas of the variables reported in table 1.

Table 1. Descriptive statistics, cronbach's coefficient alpha of the variables

\begin{tabular}{llcc}
\hline Variables & Means & Standard Deviation & Cronbach Alpha \\
\hline Modeling the way. & 3.15 & .75 & .92 \\
Challenging the process. & 2.72 & .56 & .93 \\
Inspiring a shared vision. & 3.43 & .48 & .87 \\
Enabling others to act. & 3.54 & .56 & .93 \\
Encouraging the heart. & 3.20 & .35 & .80 \\
Leadership Practices & 3.21 & .50 & .93 \\
Organizational commitment & 3.54 & .47 & .83 \\
OCB & 3.77 & .45 & .95 \\
\hline
\end{tabular}

The correlations among variables are reported in Table 2. All leadership practices were found to have a positive relationship with OCB. Leadership practices as a set also have a positive relationship with OCB. Similarly, Leadership practices - as a set - correlated with organizational commitment. Moreover, all of the five leadership practices were found to have a positive relationship with organizational commitment; Table 2 also reported the relationship between organizational commitment and OCB.

Table 2. Correlations among variables

\begin{tabular}{lcccccccc}
\hline \multicolumn{1}{c}{ Variable } & 1 & 2 & 3 & 4 & 5 & 6 & 7 & 8 \\
\hline (1) Modeling the way & & & & & & & \\
(2) Challenging the process & $.85^{* *}$ & & & & & & \\
(3) Inspiring a shared vision & $.85^{* *}$ & $.97^{* *}$ & & & & & \\
(4) Enabling others to act & $.80^{*}$ & $.49^{* *}$ & $.43^{* *}$ & & & & \\
(5) Encouraging the heart, & $.94^{* *}$ & $.80^{* *}$ & $.75^{* *}$ & $.78^{* *}$ & & & \\
(6) Leadership Practices (Total) & $.98^{* *}$ & $.91^{* *}$ & $.90^{* *}$ & $.78^{* *}$ & $.94^{* *}$ & & \\
(7) Organizational Commitment & $.87^{* *}$ & $.96^{* *}$ & $.97^{* *}$ & $.43^{* *}$ & $.83^{* *}$ & $.89^{* *}$ & \\
(8) OCB & $.97^{* *}$ & $.92^{*}$ & $.92^{* *}$ & $.72^{* *}$ & $.88^{* *}$ & $.98^{* *}$ & $.92^{* *}$ \\
\hline
\end{tabular}

Correlation is significant $* \mathrm{p}<0.05$, and $* * \mathrm{p}<0.01$

Since the p-value (sig.) in table 3 is less than 0.01 for Leadership practices, it is indicate that leadership practices are significant in explaining OCB. In the same way, the p-value for organizational commitment indicates that organizational commitment is also significant in explaining OCB. In addition, according to table 4, the R value (correlation coefficient) between independent variables (Leadership practices, Organizational commitment) and 
OCB is a positive number 0.986 which indicates high correlation between independent variables and dependent variable. The results also show that adjusted $R$ square is equal to 0.971 , which means that $97.1 \%$ of the variation in OCB is explained by the two independent variables. From the results in Table 2, hypothesis 1 - 'leadership practices are positively related to OCB' was supported, which means that by implementing the leadership practices, leaders can promote the OCB among employees. Moreover, OCB seems to be high among committed and loyal employees.

Table 3. Coefficient of multiple regressions (leadership practices and OCB)

\begin{tabular}{lccc}
\hline & $\mathrm{t}$ & Beta & Sig. \\
\hline Leadership practices & 17.42 & .797 & .000 \\
Organizational commitment & 4.81 & .207 & .000 \\
\hline
\end{tabular}

Table 4. R square and ANOVA results

\begin{tabular}{lc}
\hline \multicolumn{2}{c}{ R and ANOVA } \\
\hline $\mathrm{R}$ & .986 \\
R square & .972 \\
Adjusted R square & .971 \\
Std error Of Estimate & .074 \\
F & 1820.31 \\
Sig. & .000 \\
\hline
\end{tabular}

\subsection{Testing for Mediation}

Table 5 presents the results of the analyses leadership practices and OCB with the inclusion of organizational commitment as the mediator. According to Baron and Kenny (1986), three conditions must be met in order to say that the mediating relationship exists. First, there is a significant relationship between the independent variable and the mediator. Second, that there is a significant relationship between the independent variable and the dependent variable in the absence of the mediator. Finally, there is no significant relationship between the independent and dependent variables when both the independent and mediator element are included (Ishak 2005).

Leadership practices were found to be significantly related to OCB. Table 5 shows that Beta coefficient of the leadership practices (independent variable) and OCB (dependent variable) was positive and significant ( $(=$ 0.981, $P<0.01$ ). Moreover, the Beta coefficient of leadership practices (independent variable) and organizational commitment (mediator) were $(B=0.893, P<0.01)$. When OCB was regressed onto both organizational commitment and leadership practices respectively, the beta-weight associated with OCB showed a decrease from $.981(\mathrm{p}<.01)$ to $.797(\mathrm{p}<.01)$. Because the beta-weight associated with OCB remained significant third step, evidence was provided for partial mediation; hence, hypothesis 2 "organizational commitment mediates the relationship between leadership practices and OCB" is partially supported.

Table 5. Multiple regression beta weights for mediation relationship

\begin{tabular}{lcc}
\hline \multicolumn{1}{c}{ Variables } & Beta & Sig \\
\hline Leadership practices $>>$ OCB & .981 & .000 \\
Leadership practices $>>>$ organizational commitment & .893 & .000 \\
Leadership practices, organizational commitment $>>$ OCB & .797 & .000 \\
\hline
\end{tabular}

\section{Discussion and Conclusion}

The findings of this study revealed that leadership had a stronger positive influence on organizational citizenship behavior. Results showed that there leadership practices can play a key role in increasing both of organizational commitment and OCB among employees which - at the end - will lead to a high productive and innovative 
environment. According to the result, Most of the leadership practices have medium level of implementation in Yemeni Banks except "Challenging the process" practice which has low level of implementation. And at the same time employees reported a quiet high level organizational commitment and OCB. The findings showed that all of the leadership practices have an influence on organizational commitment. Results also indicated that all of the practices have a positive impact on OCB. In general, the relationship between leadership and employees that is characterized by setting a good example, trust, empowerment and appreciation will predict good organizational behavior like increased commitment, satisfaction, decreases turnover intentions and absenteeism.

The results demonstrated that employees will be more engaging in the OCB when the leaders being a model, set an examples of how to work effectively. Leaders will enhance OCB when the support their employees, showing the right path and helping them overcoming the problem and obstacles. In addition, by talking about the bright future for the organization and the employees, praising the good job of the employees and rewarding them, leaders promote the commitment and loyalty of their employees. In conclusion, the implementation of leadership practice will promote the OCB among employees. Current study findings suggested that the leadership should pay more attention to promote OCB because this will help organizations to work effectively and efficiently which at the end will add to the organizational success and growth.

The result also showed that hypothesis 2 was also supported. Based on the statistical result, there is a partial mediation relationship of organizational commitment between leadership practices and OCB. In other words, it seems that organizational commitment play - to a certain limit - a role in governing the relationship between leadership practices and OCB. That is because there are other variables affect the relationship between leadership practices and OCB.

\section{References}

Asgari, A., Silong, A., Ahmad, A., \& Abu, Samah, B. (2008). The Relationship between Leader-Member Exchange, Organizational Inflexibility, Perceived Organizational Support, Interactional Justice and Organizational Citizenship Behavior. African Journal of Business Management, 2(8), 138-145.

Bennis, W., \& Nanus, B. (1985). Leaders: The Strategies for Taking Charge. New York: Harper and Row.

Bono, J., \& Judge, T. (2003). Self-concordance at work: Toward understanding the motivational effects of transformational leaders. Academy of Management Journal, 46(5), 554-571. http://dx.doi.org/10.2307/30040649

Chang, K., \& Chelladurai, P. (2003). Comparison of part-time workers and full-time workers: Commitment and citizenship behaviours in Korean sport organisations. Journal of Sport Management, 17(4), 394-416.

Cho, J., \& Dansereau, F. (2010) Are transformational leaders fair? A multi-level study of transformational leadership, justice perceptions, and organizational citizenship behaviors. Leadership Quarterly, 21, 409-421. http://dx.doi.org/10.1016/j.leaqua.2010.03.006

Deluga, R. (1995). The relationship between attributional charismatic leadership and organizational citizenship behaviour. Journal of Applied Social Psychology, 25(18), 1652-69. http://dx.doi.org/10.1111/j.1559-1816.1995.tb02638.x

Hampton. R., Dubinsky, A., \& Skinner, S. (1986). A model of sales supervisor leadership and retail salespeople's job-related outcomes. Journal of the Academy of Marketing Science, 14, 33-43. http://dx.doi.org/10.1007/BF02723262

Hay, M. (2002). Strategies for survival in the war of talent. Career Development International, 7(1), 52-55. http://dx.doi.org/10.1108/13620430210414883

Hedberg L., \& Helenius, M. (2007). What leaders can do to keep their key employees. Master thesis, GÖTEBORG university, Sweden.

Ishak, N. (2005). Promoting Employees' Innovativeness and Organisational Citizenship Behaviour through Superior-Subordinate Relationship in the Workplace. Research and Practice in Human Resource Management, 13(2), 16-30.

Jahangir, N., Akbar, M., \& Haq, M. (2004). Organizational Citizenship Behaviour: Its Nature and Antecedents. BRAC University Journal 1(2), 75-85.

Kouzes, J., \& Posner, B. (1987). The leadership challenge: how to get extraordinary things done in organizations. San Francisco: Jossey-Bass.

Kouzes, J., \& Posner, B. (2003). The Leadership Practices Inventory (LPI): Participant's Workbook. San 
Francisco: Pfeiffer.

Kozlowski, S., \& Doherty, M. (1989). Integration of climate and leadership: examination of a neglected issue. Journal of Applied Psychology, 74, 546-553. http://dx.doi.org/10.1037/0021-9010.74.4.546

Lin, R., Li, H., \& Hsiao, J. (2012). What are the Relationships Between Transformational Leadership and Organizational Citizenship Behavior?-An Empirical Study. Paper presented at 2012 International Conference on Economics, Business Innovation- ICEBI 2012. Kuala Lumpur, Malaysia.

Meyer, J., \& Allen, N. (1991). A three component conceptualization of organizational commitment. Human Resources Management Review, 1, 61-89. http://dx.doi.org/10.1016/1053-4822(91)90011-Z

Meyer, J., \& Allen, N. (1996). Affective, continuance, and normative commitment to the organization: An examination of construct validity. Journal of Vocational Behavior, 49, 252-276. http://dx.doi.org/10.1006/jvbe.1996.0043

Meyer, J., Allen, N., \& Gellatly, I. (1990). Affective and continuance commitment to the organization: Evaluation of measures and analysis of concurrent and time-lagged relations. Journal of Applied Psychology, 75, 710-720. http://dx.doi.org/10.1037/0021-9010.75.6.710

Mirza, S. (2005). Job satisfaction among research and development scientists: the relationship between leadership practices and job characteristics. Ph.D. dissertation, Capella University, San Francisco, U.S.A.

Mowday, R., Steers, R., \& Porter, L. (1979). The measurement of organizational commitment. Journal of Vocational Behavior, 14, 224-247. http://dx.doi.org/10.1016/0001-8791(79)90072-1

Organ, D. (1988). Organisational citizenship behaviour: The good soldier syndrome. Lexington, MA: Lexington Books.

Podsakoff, N., Whiting, S., Podsakoff, P., \& Blume, B. (2009). Individual- and organizational level consequences of organizational citizenship behaviors: A metaanalysis. Journal of Applied Psychology, 94, 122-141. http://dx.doi.org/10.1037/a0013079

Podsakoff, P., \& MacKenzie, S. (1994). An examination of the psychometric properties and nomological validity of some revised and reduced substitutes for leadership scales. Journal of Applied Psychology, 79, 702-713. http://dx.doi.org/10.1037/0021-9010.79.5.702

Podsakoff, P., MacKenzie, S., \& Bommer, W. (1996). Transformational leader behaviors and substitutes for leadership determinants of employee satisfaction, commitment, trust, and organizational citizenship behaviors. Journal of Management, 22, 259-298.

Podsakoff, P., MacKenzie, S., Moorman, R., \& Fetter, R. (1990). Transformational leader behaviours and their effects on followers' trust in leader, satisfaction and organisational citizenship behaviours. Leadership Quarterly, 1(2), 107-142. http://dx.doi.org/10.1016/1048-9843(90)90009-7

Posdakoff, P., MacKenzie, S., Paine, B., \& Bachrach, D. (2000). Organizational citizenship behavior: A critical review of the theoretical and empirical literature and suggestions for future research. Journal of Management, 26(3), 513-563. http://dx.doi.org/10.1177/014920630002600307

Sosik, J. (2005). The role of personal values in the charismatic leadership of corporate managers: A model and $\begin{array}{lllll}\text { preliminary field } & \text { Ludy. }\end{array}$ http://dx.doi.org/10.1016/j.leaqua.2005.01.002

Stewart, Wherry, H. (2012). Authentic leadership, leader-member exchange, and organizational citizenship behavior: A multilevel analysis. Doctoral dissertation, University of Nebraska-Lincoln, Lincoln, NE.

Van, Scotter, J. (2000). Relationships of task performance and contextual performance with turnover, job satisfaction, and affective commitment. Human Resource Management Review, 10, 79-95. http://dx.doi.org/10.1016/S1053-4822(99)00040-6

Wagner, S., \& Rush, M. (2000). Altruistic organizational citizenship behavior: Context, disposition, and age. The Journal of Social Psychology, 140, 379-391. http://dx.doi.org/10.1080/00224540009600478

Walumbwa, F., Hartnell, C., \& Oke, A. (2010). Servant leadership, procedural justice climate, service climate, employee attitudes, and organizational citizenship behavior: A cross-level investigation. Journal of Applied Psychology, 95(3), 517-529. http://dx.doi.org/10.1037/a0018867

Walumbwa, F., Orwa, B., Wang, P., \& Lawler, J. (2005). Transformational leadership, organizational commitment, and job satisfaction: A comparative study of Kenyan and U.S. financial firms. Human 
Resource Development Quarterly, 16(2), 235-256. http://dx.doi.org/10.1002/hrdq.1135

Walz, S., \& Niehoff, B. (2000). Organizational citizenship behaviors: Their relationship to organizational effectiveness. Journal of Hospitality \& Tourism Research, 24, 108-126. http://dx.doi.org/10.1177/109634800002400301

Yen, H., \& Niehoff, B. (2004). Organizational Citizenship Behaviors and Organizational Effectiveness: Examining Relationships in Taiwanese Banks. Journal of Applied Social Psychology, 34(8), 1617-1637. http://dx.doi.org/10.1111/j.1559-1816.2004.tb02790.x 